\title{
Effect of Calcium Polysulfide Applications on Severity of Cocoa Pod Rot (Phytophthora palmivora Butl.) and Fungal Diversity
}

\author{
Wahyu Widiyasmoro ${ }^{1,2^{*}}$, Mintarto Martosudiro², Liliek Sulistyowati² \\ ${ }^{1}$ Surabaya Estate Crops Regional Center of Seed and Plant Protection, Jombang, Indonesia \\ ${ }^{2}$ Faculty of Agriculture, University of Brawijaya, Malang, Indonesia
}

\begin{abstract}
Indonesian government gives a high priority for the development and revitalization of cocoa production. In 2012/2013, production of cocoa in Indonesia reached 410,000 ton from 1,774,500 ha (about $231 \mathrm{~kg} \mathrm{ha}^{-1}$ ), lower than Ghana which is 835,000 ton from $1,600,300$ ha (about $521 \mathrm{~kg} \mathrm{ha}^{-1}$ ). One of the constraints of cocoa production in Indonesia is pod rot disease caused by Phytophthora palmivora, which can reduce about $90 \%$ of production during wet season. Calcium polysulfide was suggested as one of the potential, cheap and save substance to control $P$. palmivora. The purpose of this study was to evaluate the calcium polysulfide potential to control the disease and its effect on the phyllosphere-fungal diversity. A positive correlation was found between concentration of calcium polysulfide and inhibition of fungal growth in the media. Otherwise, a negative correlation was found between concentration of calcium polysulfide and fungal biomass. Disease severity of cocoa treated by calcium polysulfide $80 \mathrm{~mL} \mathrm{~L}^{-1}$ every week was $11.67 \%$ significantly lower than control, i.e. $68.33 \%$. Furthermore, it was also found that the index value of fungal diversity on the phyllosphere decreased by increasing concentration and interval of calcium polysulfide application.
\end{abstract}

Keywords: Calcium polysulfide, Cocoa, Phytophthora palmivora.

\section{INTRODUCTION}

Indonesia is one of the world's largest cocoa producers. In 2012/2013 Indonesia's cocoa production is in third position after Ivory Coast and Ghana. Indonesia cocoa production reached 410.000 tons, while Ivory Coast and Ghana are 1.449 .000 and 835.000 tons respectively [1]. Cocoa cultivated area in Indonesia is $1,774,500$ ha, not less than Ghana which is $1,600,300$ ha [2]. However, Indonesia's cocoa production is still lower than Ghana.

One of the constraints of cocoa production in Indonesia is pod rot disease. Umayah and Purwantara collected twenty Phytophthora palmivora isolates from six provinces of cocoa producer area in Indonesia that cause cacao pod rot and stem cancer [3]. This disease can cause yield loss up to $90 \%$ especially in rainy or dry season on land with a large ants population [4]. The symptoms of cocoa pod rot can be found from the base, middle, tip, old fruit, young fruit, cherelle, fruit located below, in the middle, or at the top of tree. If the fruit is symptomatically affected by pod rot, it will split then flesh shown and seeds rotten, into brown-

\footnotetext{
* Correspondence address:

Wahyu Widiyasmoro

Email : widiyasmoro@hotmail.com; Isw-fp@ub.ac.id

Address : Faculty of Agriculture, University of Brawijaya, Veteran Malang, Malang 65145.
}

ish color. The advanced infection stage, cocoa beans wrinkled and color changed to black and mummified [5]. This condition cause yield loss and poor seeds quality [6].

Calcium polysulfide is one of the potential control for pod rot plant disease. Although classified as synthetic inorganic fungicide and possibly affect the microflora on cocoa surface, but calcium polysulfide is allowed in organic farming and relatively safe to the environment [7-12]. Calcium polysulfide is capable to kill spores by disrupting the electron transport [13] as well as penetrating the fungal mycelium so that the fungus dies [14]. Affects the respiratory complexes of mitochondria by disrupting the flow of electrons in the respiratory chain, causing multi-site toxicity on a broad spectrum $[15,16]$. Affects enzymes in mitochondria [17]. Calcium polysulfide toxicity against non-target organisms is between non-toxic to moderate toxicity [18-21]. The purpose of this study were to evaluate the calcium polysulfide potential to control the disease and its effect on the phyllosphere-fungal diversity.

\section{MATERIALS AND METHODS In Vitro}

The used experimental method is poisoned food technique. The experiment was prepared based on a complete randomized design, 
consist of seven treatments and four replications. Treatment test include:

C : Vegetable 8 Juice Agar (V8JA);

$\mathrm{CP}_{5}: \mathrm{V} 8 \mathrm{JA}+5 \mathrm{ml} \mathrm{L}^{-1}$ of calcium polysulfide

$\mathrm{CP}_{10}: \mathrm{V} 8 \mathrm{JA}+10 \mathrm{ml} \mathrm{L}^{-1}$ of calcium polysulfide

$\mathrm{CP}_{20}: \mathrm{V} 8 \mathrm{JA}+20 \mathrm{ml} \mathrm{L}^{-1}$ of calcium polysulfide

$\mathrm{CP}_{40}: \mathrm{V} 8 \mathrm{JA}+40 \mathrm{ml} \mathrm{L}^{-1}$ of calcium polysulfide

$\mathrm{CP}_{80}: \mathrm{V} 8 \mathrm{JA}+80 \mathrm{ml} \mathrm{L}^{-1}$ of calcium polysulfide

$\mathrm{M}_{2}: \mathrm{V} 8 \mathrm{JA}+2 \mathrm{~g} \mathrm{~L}^{-1}$ of Mancozeb.

\section{Relative Growth Inhibition and P. palmivora} Biomass

Colonies diameter of $P$. palmivora for each replication was calculated from four quadrants, i.e. two transverse diameters and two longitudinal diameters. The influence of treatment on pathogen growth is showed in (\%) value of relative growth inhibition (RGI) against control [22]:

$\frac{\text { colony diameter of control-colony diameter of treated fungi }}{\text { colony diamter of control }} \times 100 \%$

Biomass observation of $P$. palmivora, colonies on the surface of V8JA medium were washed with $10 \mathrm{~mL} \mathrm{HCl} 4 \%$. Filtered by No. 1 Whatman filter paper (filter paper weight has been known previously) and rinsed three times. Then dried in an oven with $70^{\circ} \mathrm{C}$ temperature for 3 days. After that the dry weight of $P$. palmivora was calculated from the dry weight difference between the empty filter paper and the filter paper contain $P$. palmivora.

\section{In Vivo}

The experiments were prepared based on factorial randomized block design, with 4 treatments and 3 replications. Each replication consists of 20 sample units (cocoa pod). Based on in-vitro experiment, obtained the best concentration of calcium polysulfide is 40 and 80 $\mathrm{mL} \mathrm{L}^{-1}$ which used as in-vivo calcium polysulfide concentrations.

The first tested factor is concentration, consist of four levels: C: Control is sprayed with water; $\mathrm{CP}_{40}$ : $40 \mathrm{~mL} \mathrm{~L}^{-1}$ of calcium polysulfide; $\mathrm{CP}_{80}$ : $80 \mathrm{~mL} \mathrm{~L}^{-1}$ of calcium polysulfide; $\mathrm{M}_{2}: 2 \mathrm{~g} \mathrm{~L}^{-1}$ of mancozeb. The second factor is interval applications, which consists of three factors: once in a week, once in two weeks and once in four weeks.

\section{Cocoa Pod Rot Attack Intensity}

Observations on $P$. palmivora attack intensity were conducted once in a week and calculate using formula [23]:

$$
I=\frac{\sum(n i \times V i)}{N \times Z} \times 100 \%
$$

Description:

I = Attack intensity (\%)

$\mathrm{N}=$ Number of pod observed

$\mathrm{V}=$ Value of damage scale

$\mathrm{Z}$ = The highest scale value

$\mathrm{n} \quad$ = Number of damaged pod

Value of damage scale (V):

Score 0: healthy, no symptoms

Score 1: small, symptoms of pod infection $<25 \%$;

Score 3: moderate, symptoms of pod infection $25 \% \leq$ $x<50 \%$;

Score 9: severe, symptoms of infection $\geq 50 \%$

\section{Level of Eficacy}

Fungicide level of efficacy calculation conducted at last observation. Fungicide are effective when level of efficacy value $>50 \%$ and significantly different with control. Calculation using formula [24]:

$$
\text { Level of Eficacy }=\frac{\text { Iac }- \text { Iat }}{\text { Iac }} \times 100 \%
$$

\section{Description:}

lac = Pathogen intensity of attack on control lat $=$ Pathogen intensity of attack on fungicide treatment

\section{Fungal Diversity on the Phyllosphere}

Cocoa pod sampling for fungal diversity were taken before application, $13^{\text {th }}$ week and $21^{\text {st }}$ week. To calculate fungal diversity using Shannon index formula $\left(H^{\prime}\right)$ [25]. Species diversity index can be defined as high diversity if the value of $\mathrm{H}^{\prime}$ $>3$, medium diversity if $1 \leq H^{\prime} \leq 3$, low diversity if $\mathrm{H}^{\prime}<1$ [26].

$$
H^{\prime}=\sum p_{i} \operatorname{Ln} p_{i}, \text { where } P i=\frac{n_{i}}{N}
$$

Description:

$\mathrm{n}_{\mathrm{i}}=$ the number of individuals (isolate) in each spesies

$\mathrm{N}=$ the total number of isolates

\section{RESULT AND DISCUSSION}

\section{Relative Growth Inhibition (\%)}

Observation in two days after inoculation on $80 \mathrm{~mL} \mathrm{~L}^{-1}$ calcium polysulfide concentration was significantly different from 5,10 and $20 \mathrm{~mL} \mathrm{~L}^{-1}$ calcium polysulfide concentrations and also the control (Fig. 2). Colonies diameter of $P$. palmivora on media treated with calcium polysulfide was smaller than control colony diameter. Likewise, enhancement of calcium polysulfide concentrations also causes decreasing $P$. palmivora colonies diameter (Fig. 1 and Fig. 2). One level increase of calcium polysulfide concentration causes an increase in $5.978 \%$ relative growth inhibition $\mathrm{y}=-\mathbf{2 . 4 9 8}+\mathbf{5 . 9 7 8 x}$ (Fig. 3). 


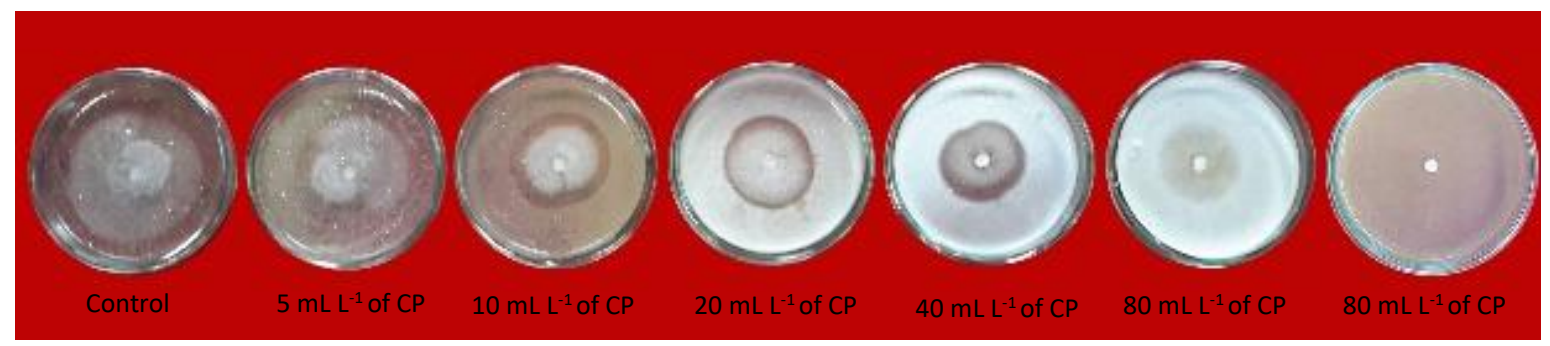

Figure 1. P. palmivora colonies diameter (circled in red) at 6 day after inoculation $\mathrm{CP}$ : Calcium polysulfide; M: Mancozeb

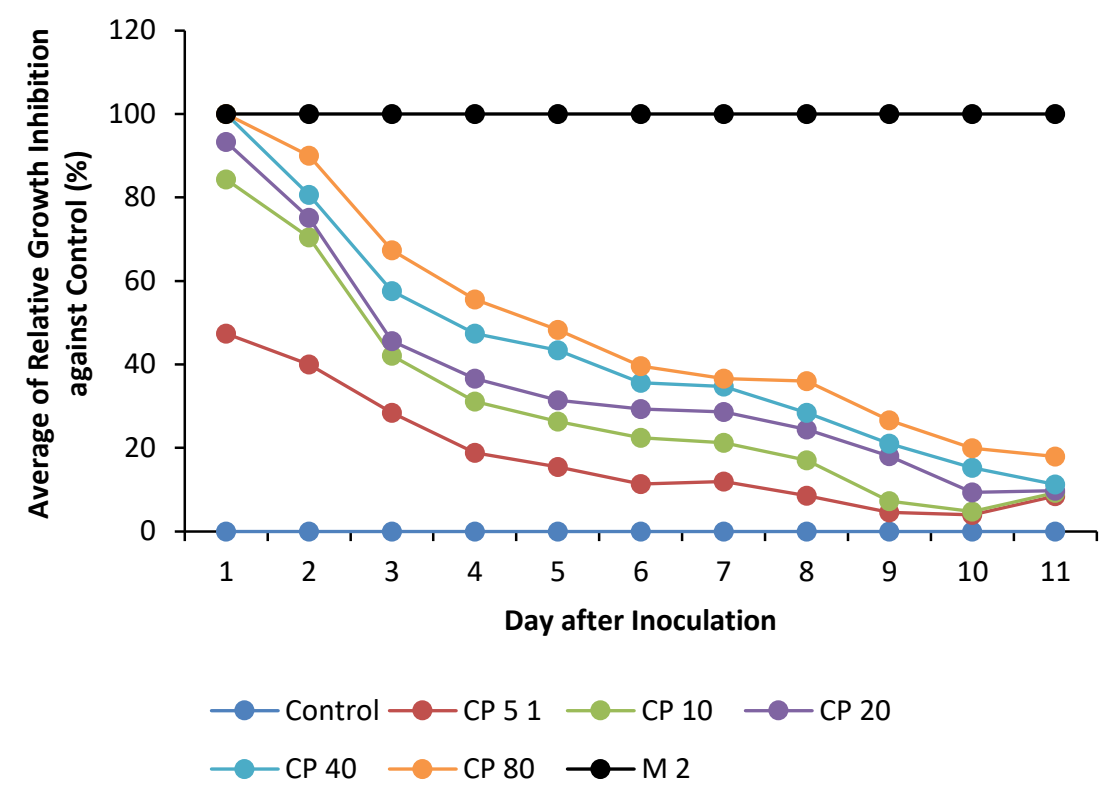

Figure 2. Effect of Calcium Polysulfide Concentration against Average of Relative Growth Inhibition against Control (\%) CP: Calcium polysulfide $\left(\mathrm{mL} \mathrm{L}^{-1}\right)$; $\mathrm{M}$ : Mancozeb $\left(\mathrm{g} \mathrm{L}^{-1}\right)$

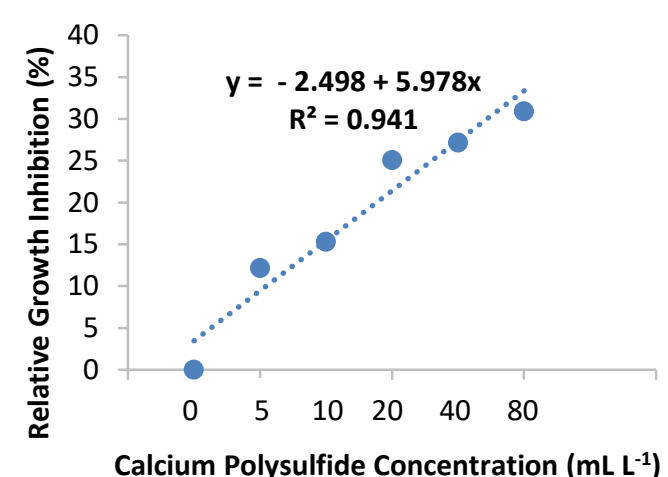

Figure 3. Regression between Calcium Polysulfide Concentration with Relative Growth Inhibition

\section{Biomass of $\boldsymbol{P}$. palmivora}

Biomass is influenced by the fungi component such as mycelia that is formed. The colony diameter on calcium polysulfide treatment is smaller and thinner than the control. Similarly, comparison between calcium polysulfide concentrations also shows differences in $P$. palmivora diameter colonies and its thickness. The high calcium polysulfide concentration causes colony diameter become small and thin (Fig. 1). Its known that $80 \mathrm{~mL} \mathrm{~L}^{-1}$ calcium polysulfide treatment is significantly different from the other treatments and is not significantly different from $40 \mathrm{~mL} \mathrm{~L}^{-1}$ calcium polysulfide treatment (Table 2 ). One level increase of calcium polysulfide concentration causes a decrease in $0.004 \mathrm{~g}$ of biomass $\mathrm{y}=0.031-0.004 x$ (Fig. 4).

Table 2. Effect of Calcium Polysulfide Concentration

\begin{tabular}{|c|c|}
\hline \multicolumn{2}{|c|}{ Against Average of $P$. palmivora Biomass } \\
\hline Treatments & Biomass (mg) \\
\hline Control & $24.2 \mathrm{~b}$ \\
\hline CP $5 \mathrm{~mL} \mathrm{~L}^{-1}$ & $20.7 \quad b$ \\
\hline $\mathrm{CP} 10 \mathrm{~mL} \mathrm{~L}^{-1}$ & $20.2 \mathrm{~b}$ \\
\hline $\mathrm{CP} 20 \mathrm{~mL} \mathrm{~L}^{-1}$ & $18.9 \mathrm{~b}$ \\
\hline $\mathrm{CP} 40 \mathrm{~mL} \mathrm{~L}^{-1}$ & $8.1 \mathrm{ab}$ \\
\hline $\mathrm{CP} 80 \mathrm{~mL} \mathrm{~L}^{-1}$ & $1.5 \mathrm{a}$ \\
\hline $\mathrm{M} 2 \mathrm{~g} \mathrm{~L}^{-1}$ & $0.05 \mathrm{a}$ \\
\hline
\end{tabular}

Description: Numbers with the same letter in the same column, based on the 5\% DMRT show no significant difference; CP: Calcium polysulfide; M: Mancozeb. 


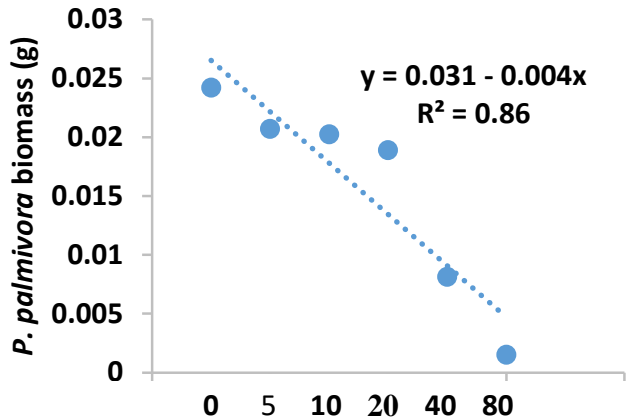

Calcium Polysulfide Concentration $\left(\mathrm{mL} \mathrm{L}^{-1}\right)$

Figure 4. Regression between calcium polysulfide Concentration with $P$. palmivora biomass

\section{Cocoa Pod Rot Attack Intensity}

Observation and data analysis on cocoa pod rot ( $P$. palmivora) intensity of attack was conducted every week until $21^{\text {st }}$ week. There is interaction between treatments (4 levels) with applications interval ( 3 levels). The interaction occurred in the $2^{\text {nd }}$ and $7^{\text {th }}-9^{\text {th }}$ week observation (Table 3). This shows that the influence of each factor is not same for every other level of factor.

In general, observations at $7^{\text {th }}-9^{\text {th }}$ weeks of $80 \mathrm{~mL} \mathrm{~L}^{-1}$ calcium polysulfide treatment showed a significant effect on intensity of cocoa pod rot attack mean than other treatments at each level of applications interval. Calcium polysulfide 40

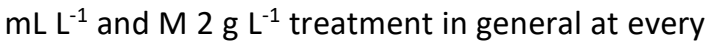
level of application interval showed that average cocoa pod rot attack intensity was not significantly different except with $80 \mathrm{~mL} \mathrm{~L}^{-1}$ calcium polysulfide and control treatment. Once in a week application interval of $80 \mathrm{~mL} \mathrm{~L}^{-1}$ calcium polysulfide was found as the best treatment to control the disease.

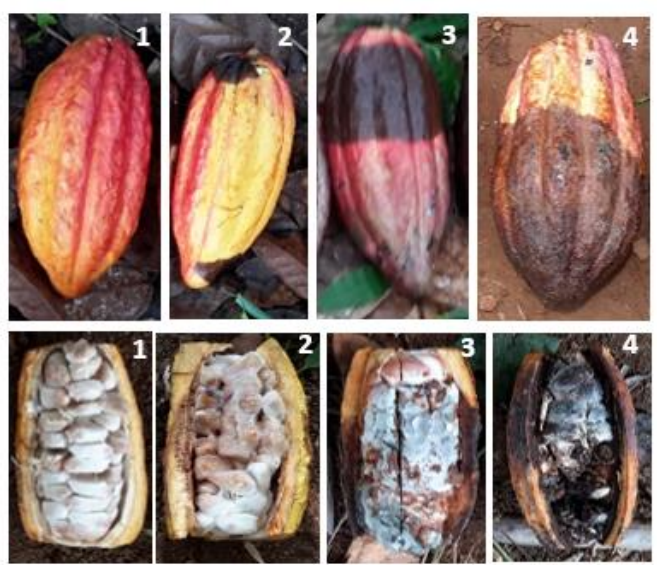

Figure 5. Cocoa Pod Rot Attack Intensity (1: Healthy; 2: Small attack; 3: Moderate attack; 4: Severe attack)

\section{Fungicide Level of Eficacy}

Level of efficacy value at once in a week application interval of $80 \mathrm{~mL} \mathrm{~L}^{-1}$ calcium polysulfide is $70 \%$ (Table 4 ). This is effective for controling cocoa pod rot in-vivo, because efficication rate value more than $50 \%$ and significantly different compared with control.

Table 4. Level of Eficacy (\%) at the Last Observation

\begin{tabular}{|c|c|c|c|}
\hline \multirow{2}{*}{ Treatments } & \multicolumn{3}{|c|}{$\begin{array}{l}\text { Application Intervals } \\
\text { (once in ... week) }\end{array}$} \\
\hline & 1 & 2 & 4 \\
\hline Control & $0.00 \mathrm{a}$ & $0.00 \mathrm{a}$ & $0.00 \mathrm{a}$ \\
\hline $\mathrm{CP} 40 \mathrm{~mL} \mathrm{~L}^{-1}$ & $20.33 \mathrm{~b}$ & $11.85 \mathrm{~b}$ & $7.33 \mathrm{k}$ \\
\hline $\mathrm{CP} 80 \mathrm{~mL} \mathrm{~L}^{-1}$ & $70.00 \mathrm{c}$ & $47.79 \mathrm{c}$ & 35.00 \\
\hline $\mathrm{M} 2 \mathrm{gL}^{-1}$ & $23.33 \mathrm{~b}$ & $8.47 \quad b$ & $6.33 \mathrm{k}$ \\
\hline
\end{tabular}

Description: Numbers with the same letter in the same column, based on 5\% DMRT show no significant difference. Data is transformed to $\arcsin V x$ for statistical analysis. CP: Calsium polysulfide; M: Mancozeb.

Table 3. Effect of Calcium Polysulfide Concentration against Average of Cocoa Pod Rot (P. palmivora) Intensity of Attack (\%)

\begin{tabular}{|c|c|c|c|c|c|c|c|c|c|}
\hline \multirow{3}{*}{$\begin{array}{c}\text { Treatments } \\
\text { Control }\end{array}$} & \multirow{3}{*}{$\begin{array}{c}\begin{array}{c}\text { Application } \\
\text { Intervals } \\
\text { (...once a } \\
\text { week) }\end{array} \\
1\end{array}$} & \multicolumn{8}{|c|}{ Observations } \\
\hline & & \multicolumn{2}{|c|}{$2^{\text {nd }}$ Week } & \multicolumn{2}{|c|}{$7^{\text {th }}$ Week } & \multicolumn{2}{|c|}{$8^{\text {th }}$ Week } & \multicolumn{2}{|c|}{$9^{\text {th }}$ Week } \\
\hline & & 0.33 & $a b$ & 62.67 & gh & 62.67 & $\mathrm{e}$ & 68.33 & ef \\
\hline & 2 & 2.00 & $b$ & 65.67 & $\mathrm{~h}$ & 71.00 & $f$ & 85.00 & g \\
\hline & 4 & 5.33 & c & 88.33 & i & 88.33 & g & 89.00 & g \\
\hline $\mathrm{CP} 40 \mathrm{~mL} \mathrm{~L}^{-1}$ & 1 & 0.67 & $a b$ & 49.33 & e & 58.38 & de & 72.00 & f \\
\hline \multirow[t]{3}{*}{ CP $80 \mathrm{~mL} \mathrm{~L}^{-1}$} & 4 & 0.33 & $a b$ & 10.00 & $\mathrm{a}$ & 11.00 & $a$ & 11.67 & $\mathrm{a}$ \\
\hline & 2 & 0.00 & $\mathrm{a}$ & 17.00 & $b$ & 17.67 & $b$ & 18.00 & $b$ \\
\hline & 1 & 1.00 & $a b$ & 30.67 & C & 35.33 & c & 42.67 & $\mathrm{c}$ \\
\hline $\mathrm{M} 2 \mathrm{gL}^{-1}$ & 4 & 2.67 & $b$ & 52.00 & ef & 52.67 & $d$ & 59.33 & $d$ \\
\hline
\end{tabular}

Description: Numbers with the same letter in the same column, based on 5\% DMRT show no significant difference. Data is transformed to $\sqrt{ } \times\left(2^{\text {nd }}\right.$ week $)$; arcsin $\sqrt{ } x\left(7^{\text {th }}-9^{\text {th }}\right.$ week) for statistical analysis. CP: Calcium polysulfide; M: Mancozeb 


\section{Fungi Diversity on Cocoa Pod Surface}

In general, the fungi diversity index has decreased, where the highest decrease occurred in once a week application interval of $80 \mathrm{~mL} \mathrm{~L}^{-1}$ calcium polysulfide treatment (Fig. 6). But from the third time cocoa pod sampling from the field, according to Fachrul [26] fungi diversity index is still categorized as medium (1.08-1.93).

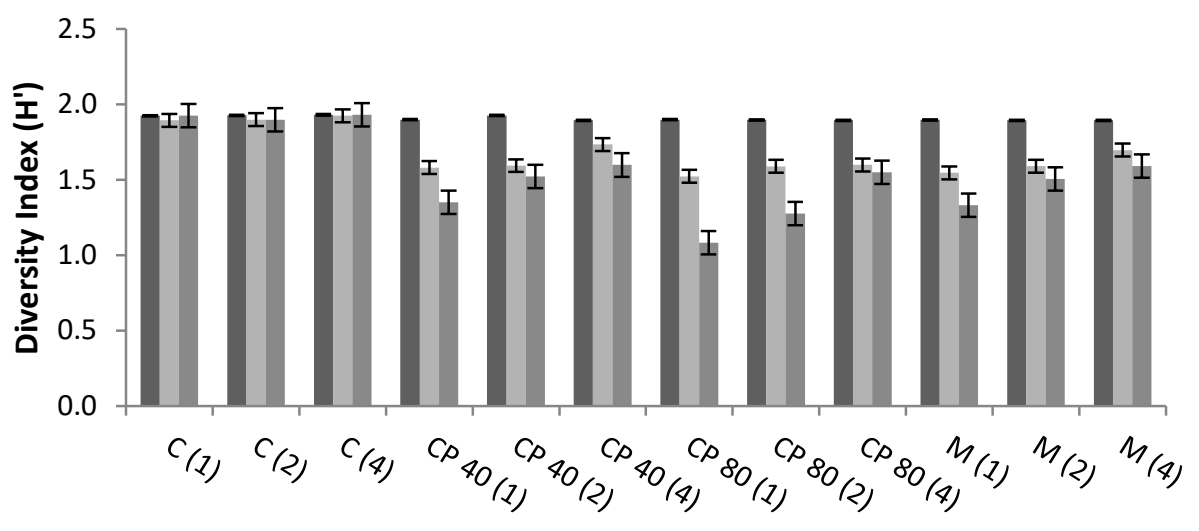

Treatment

- Fungi diversity index before apllication $\square$ Fungi diversity index at 13th week

Fungi diversity index at 21st

Figure 6. Fungi Diversity Index on Cocoa Pod Surface

C: Control: CP 40: $40 \mathrm{~mL} \mathrm{~L}^{-1}$ of calcium polysulfide; CP 80: $80 \mathrm{~mL} \mathrm{~L}^{-1}$ of calcium polysulfide; $\mathrm{M}: 2 \mathrm{~g} \mathrm{~L}^{-1}$ of Mankozeb; 1 , 2, 4: Applications Interval (once in ... week)

\section{Discussion}

Calcium polysulfide has ability to inhibit growth, affect the biomass, affect the $P$. palmivora intensity of attack and affect the fungal diversity index. Because sulfur content in calcium polysulfide can inhibit fungal enzymes [27]. Sulfur affects fungal enzymes that can prevent mycelial growth [28]. Indicates the presence of polyphenols oxidation inhibition [27,29].

Calcium polysulfide is able to penetrate fungi mycelium so that the fungus dies [20]. Sulfur affects complex mitochondrial respiration by interrupting flow of electrons in respiratory chain, leading to multi-site toxicity $[15,16,30]$.

Calcium polysulfide kills germinated spores [31]. This mode of action involves the interception of electrons in effective respiration chain by reducing element of sulfur to hydrogen sulfide, which is also toxic to cell proteins $[16,32]$.

Sulfur as an effective inhibitor of conidia formation and germination and may affect multiple target sites in fungal cells. Among others, by inhibiting respiration by receiving electrons in the cytochrome $c$ region that can interfere with proteins and bind heavy metals in cells $[28,33,34]$.

At conidia, calcium polysulfide is able to prevent citrate production from exogenous acetate, and causes increased succinate, indicating enzymes blockage in pathway between acetate and citrate and inhibiting the succinoxidase system in Krebs cycle [35]. Sulfur as a hydrogen acceptor and provides interference in dehydrogenation reaction [34]. Free radicals from sulfur are formed in the sulfur-polysulfide$\mathrm{H}_{2} \mathrm{~S}$ conversion and these are highly reactive free radicals, which are toxic [35].

Some enzymes that can be disturbed by calcium polysulfide i.e. tricarboxylic acid enzymes, hexokinase enzymes, triosphosphate dehydrogenase enzymes, aldolase enzymes, cocarboxylase enzymes, thiamin pyrophosphate enzymes, keto acid dehydrogenase enzymes, polyphenol oxidase enzymes, citric acid synthetase enzymes, akonitase enzymes, isositrate dehydrogenase enzymes, $\alpha$ ketoglutarate dehydrogenase enzymes, succinate dehydrogenase enzymes, malate dehydrogenase enzymes and glycolytic enzymes (hexokinase, phosphohexose isomerase, phosphofructokinase, aldolase, triosa phosphate isomerase, glyceraldehyde 3-phosphate dehydrogenase, phosphoglycerate kinase, phosphoglycerate mutase, enolase and pyruvate kinase) [17].

\section{CONCLUSION}

It was found a positive correlation between concentration of calcium polysulfide and 
inhibition of fungal growth in the media. Growth inhibition of fungi in the agar medium contained calcium polysulfide 80 and $40 \mathrm{~mL} \mathrm{~L}^{-1}$ was $17.921 \%$ and $11.295 \%$ respectively, significantly higher than control. It was found a negative correlation between concentration of calcium polysulfide and fungal biomass. Fungal biomass contained calcium polysulfide 80 and $40 \mathrm{~mL} \mathrm{~L}^{-1}$ was $1.5 \mathrm{mg}$ and $8.1 \mathrm{mg}$ respectively, significantly lower than control, i.e. $24.2 \mathrm{mg}$. Disease severity of cocoa treated by calcium polysulfide $80 \mathrm{~mL} \mathrm{~L}^{-1}$ every weeks was $11.67 \%$ significantly lower than control, i.e. $68.33 \%$. Furthermore, it was also found that the index value of fungal diversity on the phyllosphere decrease by increasing concentration and interval of application calcium polysulfide.

\section{REFERENCES}

[1] International Cocoa Organisation (ICCO). 2015. Cocoa Year 2014/2015. Quarterly Bulletin of Cocoa Statistics, XLI(3). 12-35.

[2] Food and Agriculture Organization (FAO). 2013. Cocoa, beans area harvested. Available at: http://faostat3.fao.org/down oad /Q/ QC/E.

[3] Umayah, A., A. Purwantara. 2006. Identifikasi isolat Phytophthora asal KAKAO. Menara Perkebunan. 74(2). 76-85.

[4] Rosmana, A., C. Waniada, M. Junaidi, A. Gassa. 2010. Peranan semut Iridomirmex cordatus (Hyminoptera: Formicidae) dalam menularkan patogen busuk buah Phytophthora palmivora. Pelita Perkebunan. 26. 169-176.

[5] Bowers, J.H., B.A. Bailey, P.K. Hebbar, S. Sanogo, R. Lumsden. 2001. The impact of plant diseases on world chocolate production. American Phytopathological Society. Feature Story. Available at: http://www.apsnet.org/online/feature/cac ao/top.html.

[6] Rubiyo, W. Amaria. 2013. Ketahanan tanaman kakao terhadap penyakit busuk buah (Phytophthora palmivora Butl.). Perspektif. 12(1). 23-36.

[7] Smilanick J.L., D. Sorensen. 2000. Control of postharvest decay of citrus fruit with calsium polysulfide. Postharvest Biol. Tech. 21. 157-168.

[8] CAN. 2011. Organic production systems permitted substances lists: CAN/CGSB32.311-2006. Canadian General Standards Board. Available at: http://www.tpsgcpwgsc.gc.ca/ongc-cgsb/programme- program/normes- standards /internet/bioorg/documents/032-0311-2008 -eng.pdf.

[9] Codex. 2013. Guidelines for the production, processing, labeling, and marketing of organically produced foods. Codex Alimentarius Commission. Available at: http://www.codexalimentarius.org/standar ds/list-of-standards/ en/?no_cache=1.

[10] European Commission (EC). 2008. Commission Regulation (EC) No. 889/2008. European Commission. Available at: http://eur-lex.europa.eu/ LexUriServ/LexUri Serv.do?uri=OJ:L:2008:250:0001:0084:EN:P DF.

[11] IFOAM. 2014. The IFOAM norms for organic production and processing. International Federation of Organic Agriculture Movements. Available at: http://www.ifoam.org /en/ ifoam-norms.

[12] Soil Association. 2014. Soil Association organic standards, farming and growing. Revision 17.2. United Kingdom Soil Association. Available at: http://www.soil association.org/organicstandards.

[13] United State Department of Agriculture (USDA). 2014. Lime Sulfur. Technical Evaluation Report Compiled by Pesticide Research Institute for the USDA National Organic Program. USA.

[14] Holb I.J., P. de Jong, B. Heijne. 2003. Efficacy and phytotoxicity of lime sulphur in organic apple production. Ann. Appl. Biol. 142. 225-233.

[15] Holb I.J., G. Schnabel. 2008. A detached fruit study on the post-inoculation activity of lime sulfur against brown rot of peach (Monilinia fructicola). Australasian Plant Pathol. 37. 454.

[16] Beffa, T. 1993. Inhibitory action of elemental sulphur on fungal spores. Can. J. Microbiol. 39. 731-735.

[17] Lukens, R.J. 1971. Chemistry of fungicidal action. Springer. New York.

[18] US Department of Human Health Services (NIOSH). 1997. National institute for occupational safety and health pocket guide to chemical hazards. Publication No. 97-140. US Government Printing Office. Washington, DC.

[19] United State Environmental Protection Agency (US EPA). 2005. Environmental fate and ecological risk assessment for the reregistration eligibility decision document (RED) of calcium polysulfides, a fungicide /acaricide. US Environmental Protection 
Agency. Available at: //www.regulations. gov/\#!documentDetail; $\mathrm{D}=\mathrm{EPA}-\mathrm{HQ}$ - OPP 2007-0008-0004.

[20] US EPA. 2005. Reregistration eligibility decision for inorganic polysulfides. US Environmental Protection Agency. Available at: http://www.regulations.gov/\#!docume document;D=EPA-HQ-OPP-2007-0008-0002

[21] NovaSource. 2013. Safety data sheet: lime sulfur solution. EPA Reg No 61842-30. Available at: www.cdms.net/ldat/mpBA 1001.pdf.

[22] Santi, L.P., L.I. Sudirman, H.G. Didiek. 2007. Potensi fungi pelapuk putih asal lingkungan tropik untuk bioremidiasi herbisida. Menara Perkebunan. 75(1). 43-55.

[23] Sulistyowati, E. 2008. Pengendalian hama kakao. In: Wahyudi, T., T.R. Pangabean, Pujiyanto (Eds). Panduan lengkap kakao: manajemen agribisnis darihulu hingga hilir. Penebar Swadaya. Jakarta.

[24] Directorate General of Agriculture Facilities. 2013. Metode standar pengujian efikasi fungisida. Indonesian Ministry of Agriculture. Jakarta.

[25] Zak, J.C., M.R. Willig. 2004. Fungal biodiversity patterns. In: Biodiversity of Fungi: Inventory and Monitoring Methods. Elsevier.

[26] Fachrul, M.F. 2007. Metode sampling bioekologi. Bumi Aksara. Jakarta.

[27] Byrde, R.J.W., J.T. Martin, D.J.D. Nicholas. 1956. Effect fungicide on fungus enzymes. Nature. 178. 638-639.

[28] McCallan, S.E.A., L.P. Miller. 1957. Effect of fungicide on oxygen consumption and viability of mycelial Pellets. Contrib. Boyce Thompson Inst. 18. 483-495.

[29] Owens, R.G. 1953. Studies on the nature of fungicidal action. I. Inhibition of Sulfhydryl-, amino-, iron- and copper-dependent enzymes in vitro by fungicides and related compounds. Contrib. Boyce Thompson Inst. 17. 221-242.

[30] McCallan, S.E.A., L.P. Miller, R.M. Weed. 1954. Comparative effects of fungicides on oxygen uptake and germination of spores. Contribs. Boyce Thompson Inst. 18. 39-68.

[31] United State Department of Agriculture (USDA). 2014. Lime Sulfur. Technical Evaluation Report Compiled by Pesticide Research Institute for the USDA National Organic Program. USA.
[32] Janssen D. 2002. Lime-Sulfur: A fungicide used to control a variety of diseases. University of Nebraska - Lincoln Extension in Lancaster County. Available at: http://lancaster.unl.edu/hort/articles/2002 /lime-sulfur.shtml.

[33] Tweedy, B.G. 1967. Elemental sulfur. In: Torgeson, D.C. (Ed). Fungicides: an advanced treatise, Vol. 2. AcademicPress, New York. 119-145.

[34] Miller, L. P., S.E.A. McCallan, R.M. Weed. 1953. Accumulation of 2-heptadecyl-2imidazoline, silver and cerium by Fungus Spores in Mixed and Consecutive Treatments. Contribs. Boyce Thompson Inst. 17(5). 283-298.

[35] Owens, R.G. 1960. Effects of elemental sulfur, dithiocarbamates, and related fungicides on organic acid metabolism of fungus spores. Dev. Ind. Microbiol. 1. 187205. 